University of Nebraska - Lincoln

DigitalCommons@University of Nebraska - Lincoln

1989

\title{
Postsecondary Education for Students with Learning Disabilities
}

J. Ron Nelson

University of Nebraska - Lincoln, rnelson8@unl.edu

Benjamin Lignugaris/Kraft

Utah State University

Follow this and additional works at: https://digitalcommons.unl.edu/specedfacpub

Part of the Special Education and Teaching Commons

Nelson, J. Ron and Lignugaris/Kraft, Benjamin, "Postsecondary Education for Students with Learning Disabilities" (1989). Special Education and Communication Disorders Faculty Publications. 34.

https://digitalcommons.unl.edu/specedfacpub/34

This Article is brought to you for free and open access by the Department of Special Education and Communication Disorders at DigitalCommons@University of Nebraska - Lincoln. It has been accepted for inclusion in Special Education and Communication Disorders Faculty Publications by an authorized administrator of DigitalCommons@University of Nebraska - Lincoln. 


\title{
Postsecondary Education for Students with Learning Disabilities
}

\author{
RON NELSON \\ BENJAMIN LIGNUGARIS/KRAFT
}

\begin{abstract}
Increasingly, students with learning disabilities are attending community colleges and traditional 4-year colleges and universities. This article presents the results of a review of the literature on services available or recommended for students with learning disabilities. The results suggest that postsecondary institutions have begun to provide a wide array of services to these students. There is little empirical evidence, however, on the effectiveness of those services. An agenda for future research is also discussed.
\end{abstract}

Increasing numbers of students with learning disabilities are pursuing postsecondary education in community colleges and traditional 4-year higher education institutions (Adult Committee of the Association of Children with Learning Disabilities, ACLD, 1982; Decker, Polloway, \& Decker, 1985; Ostertag, Baker, Howard, \& Best, 1982; Ugland \& Duane, 1976; White et al., 1982). For example, college officials at 106 California community colleges reported that 7,982 learning disabled students were receiving services through the community college learning disability programs (Ostertag et al., 1982). Moreover, in a survey of adults with learning disabilities, $14 \%$ reported they had tried college and dropped out, $32 \%$ were currently attending college, and another 9\% reported that they had completed their bacl.. lor's degrees (White et al., 1982).

College officials have developed an increasing number of support programs in response to the influx of learning disabled students on college campuses (Mangrum \& Strichart, 1983a). The number of support programs has

RON NELSON is Doctoral Student, and BENJAMIN LIGNUGARIS/KRAFT is Assistant Professor, Department of Special Education, Utah State University, Logan. increased for several reasons. First, the enactment of Section 504 of the Rehabilitation Act of 1973 was a major impetus for establishing postsecondary programs for learning disabled students. Second, the development of services at the college level is an outgrowth of services provided initially in elementary schools and later in junior and senior high schools (Decker et al., 1985; Gray, 1981a; Mangrum \& Strichart, 1983a; Sedita, 1980). Third, the ACLD and other national and local organizations have campaigned actively to persuade college and university personnel to develop programs to assist these students on college campuses. These lobbying efforts, combined with student interest in attending college, have brought pressure on colleges to develop programs to assist students with learning disabilities (Mangrum \& Strichart, 1983a). Finally, many colleges face declining student enrollments. Learning disabled students with the potential for college success represent a source of new enrollments for colleges (Mangrum \& Strichart, 1983a).

The purpose of this paper is to review the literature on the types of services available to learning disabled students and identify additional services needed in postsecondary institutions. In addition, future research needs are discussed. 


\section{LITERATURE REVIEWED}

The literature examined was identified through a computer search of the Exceptional Child Education Resources Abstract, Dissertation Abstracts, and Psychological Abstracts. Descriptors included learning disabled, dyslexia, disabilities, academic failure, learning programs, postsecondary education, adult education, higher education, and continuing education. In addition, an ancestral search was conducted from the identified articles. Articles reviewed referred specifically to programs or discussed the need for programs for learning disabled students (or other commonly used classification labels, such as dyslexia) at community colleges or traditional 4-year higher education settings and were published following the enactment of Section 504 of the Rehabilitation Act of 1973. Articles not included in this review were those that examined specific characteristics (e.g., written language) of college learning disabled students or referred to postsecondary settings other than community colleges or traditional 4-year higher education institutions (e.g., vocational technical schools). A total of 31 articles were identified: 14 articles were surveys of services (8) to support learning disabled students in postsecondary institutions, or descriptive evaluations of specific programs (6), and 17 articles were discussion papers.

The surveys and program descriptions are presented in Table 1. (A complete listing of the discussion papers reviewed is available from the authors on request.) Respondents were identified as directors or coordinators of college learning disabilities programs, college faculty, or students with learning disabilities. In addition, each article was examined for counseling services, instructional accommodations, and administrative accommodations provided to learning disabled students.

The types of counseling services offered were delineated as personal or social, program or academic, and career or vocational counseling. Instructional accommodations included services provided by colleges and instructional adaptations left to the discretion of individual faculty. Finally, administrative accommodations included alternative admission criteria and the addition of special remedial courses to the college curricula.

\section{IDENTIFYING THE COLLEGE STUDENT WITH LEARNING DISABILITIES}

In general, a clear understanding of learning disabilities is lacking in many college programs (Cordoni, 1982a). There is little consensus on appropriate measures for identifying adults with learning disabilities (Blackburn \& Iovacchini, 1982; Cordoni, 1982a; Gray, 1981b; Hoy \& Gregg, 1986). Moreover, there is a lack of consistency in admission criteria across programs (Ostertag et al., 1982). In some colleges, services are available on request or following student and parent interviews (Blalock \& Dixon, 1982; Hoy \& Gregg, 1986), whereas other programs require lengthy psychoneurological testing or psychoeducational testing to determine if there is a significant discrepancy between aptitude and achievement (Cordoni, 1979; Gajar, Murphy, \& Hunt, 1982; Miller, McKinley, \& Ryan, 1979; Ugland \& Duane, 1976).

Some of the programs described in this review served only students who were designated as learning disabled according to the definition of learning disability found in Public Law 94-142, whereas other programs served a broad array of low-achieving students. For example, programs that admitted students based on the definition of learning disabilities found in P.L. 94-142 included Pennsylvania State University, Southern Illinois University at Carbondale, Rochester Community College, Metropolitan Community College, and Normandale Community College. In contrast, the program for students with learning disabilities at Kingsborough Community College served students with a broad array of learning difficulties and emotional problems (Siegel, 1979), and admission to the Wright State University program was based on a high-average IQ, evaluations from former teachers, a personal interview, and a 100-word statement by applicants indicating why they had applied for the program (Bireley \& Manley, 1980).

\section{SERVICES PROVIDED}

Most colleges provided similar types of services to students in learning disabled programs.

\section{Counseling Services}

Counseling services were often cited as a necessary component of a program for students 


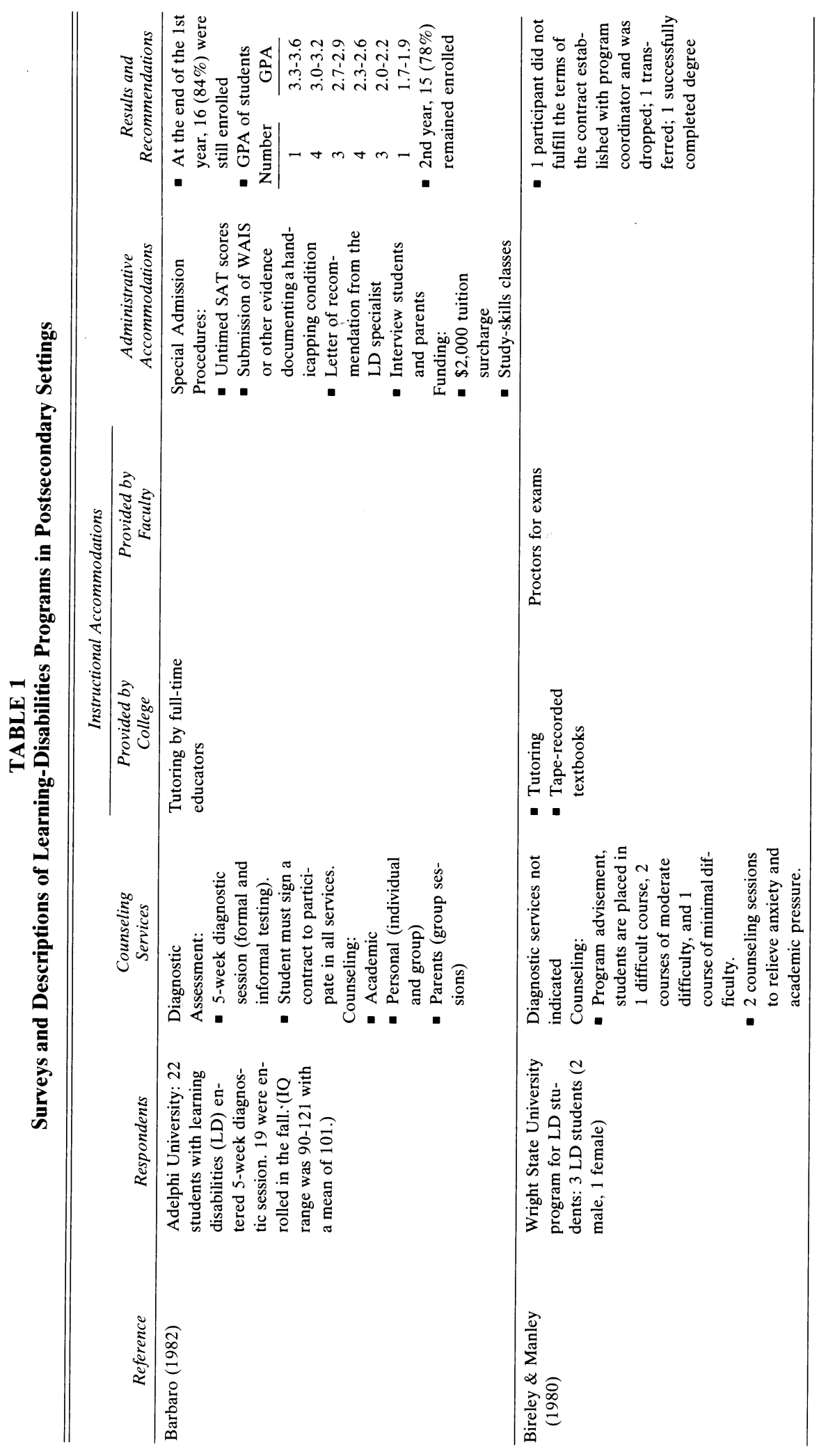

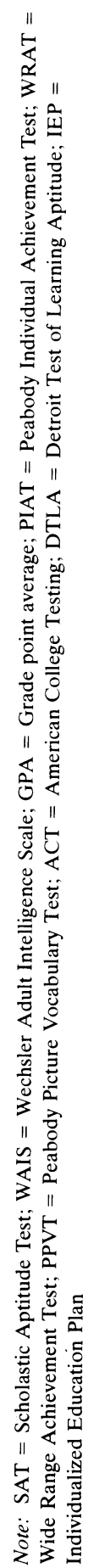




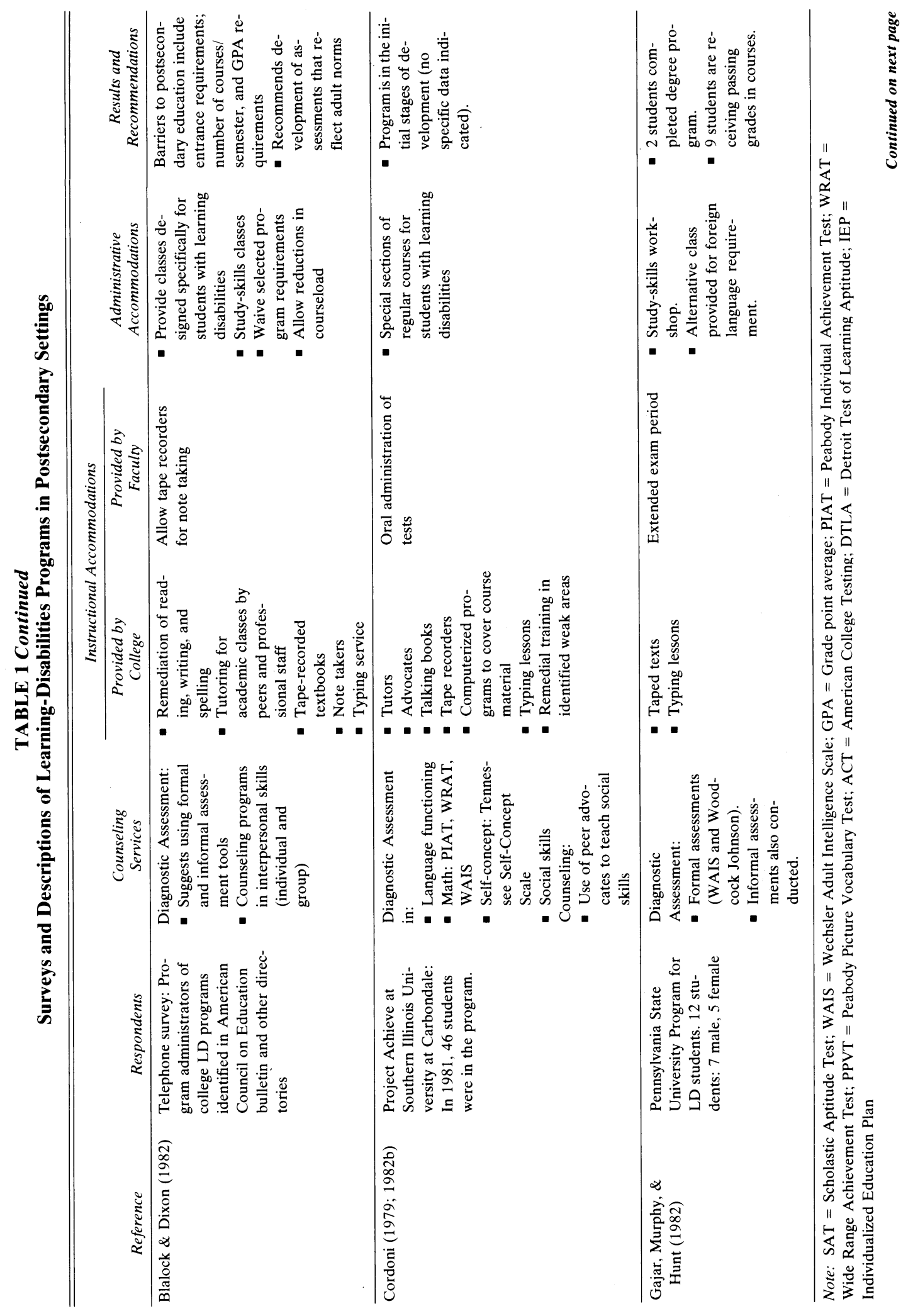




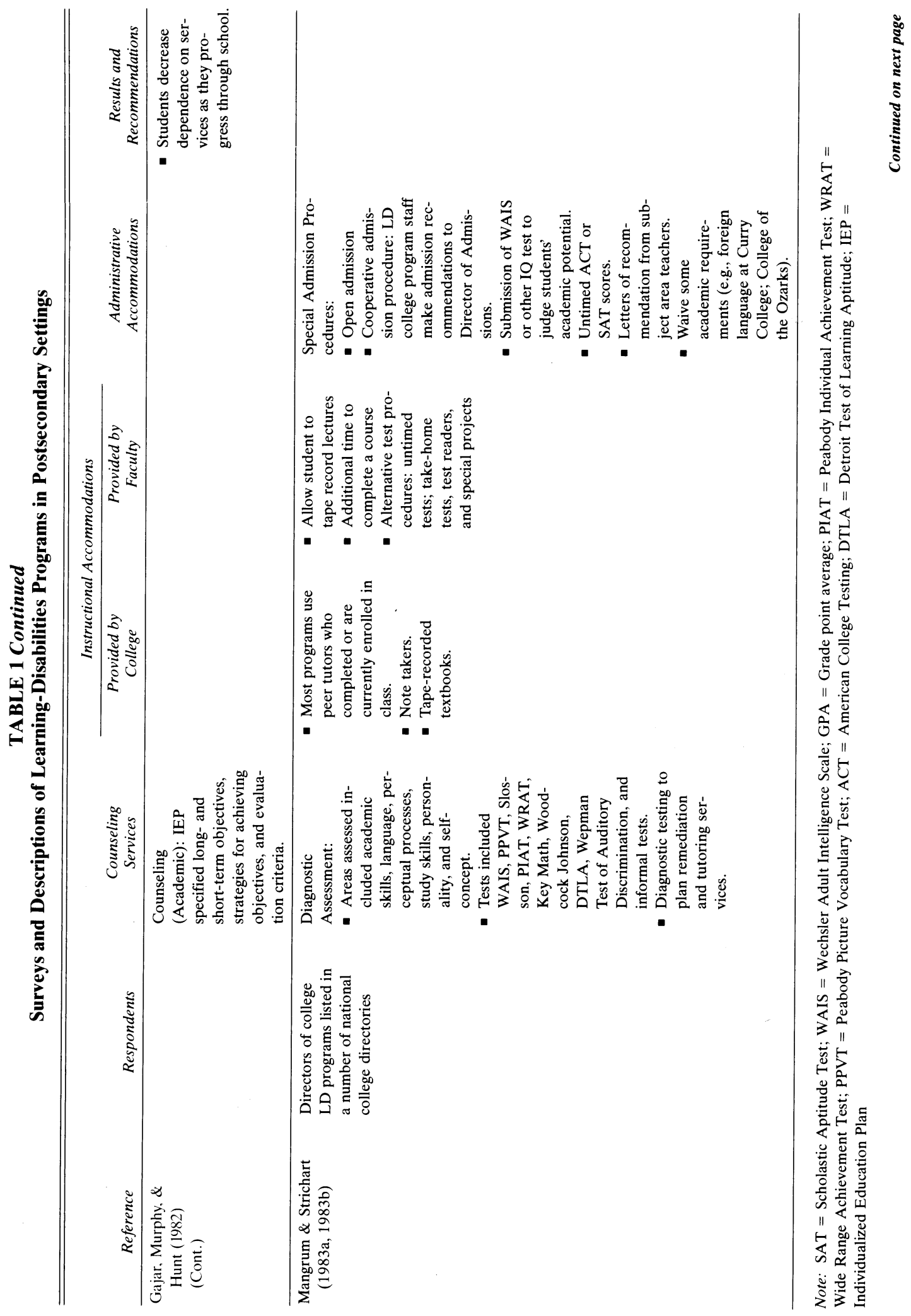




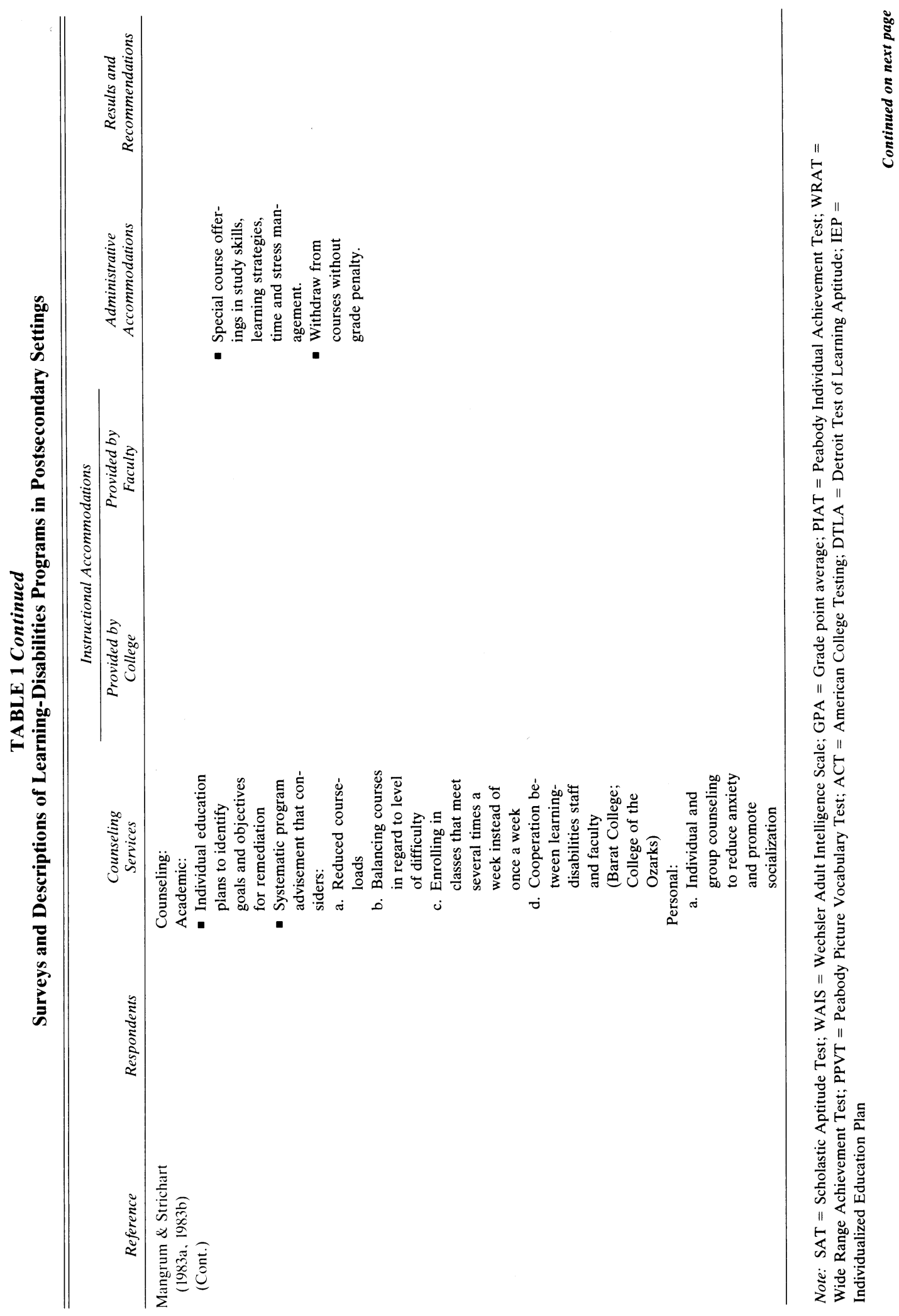



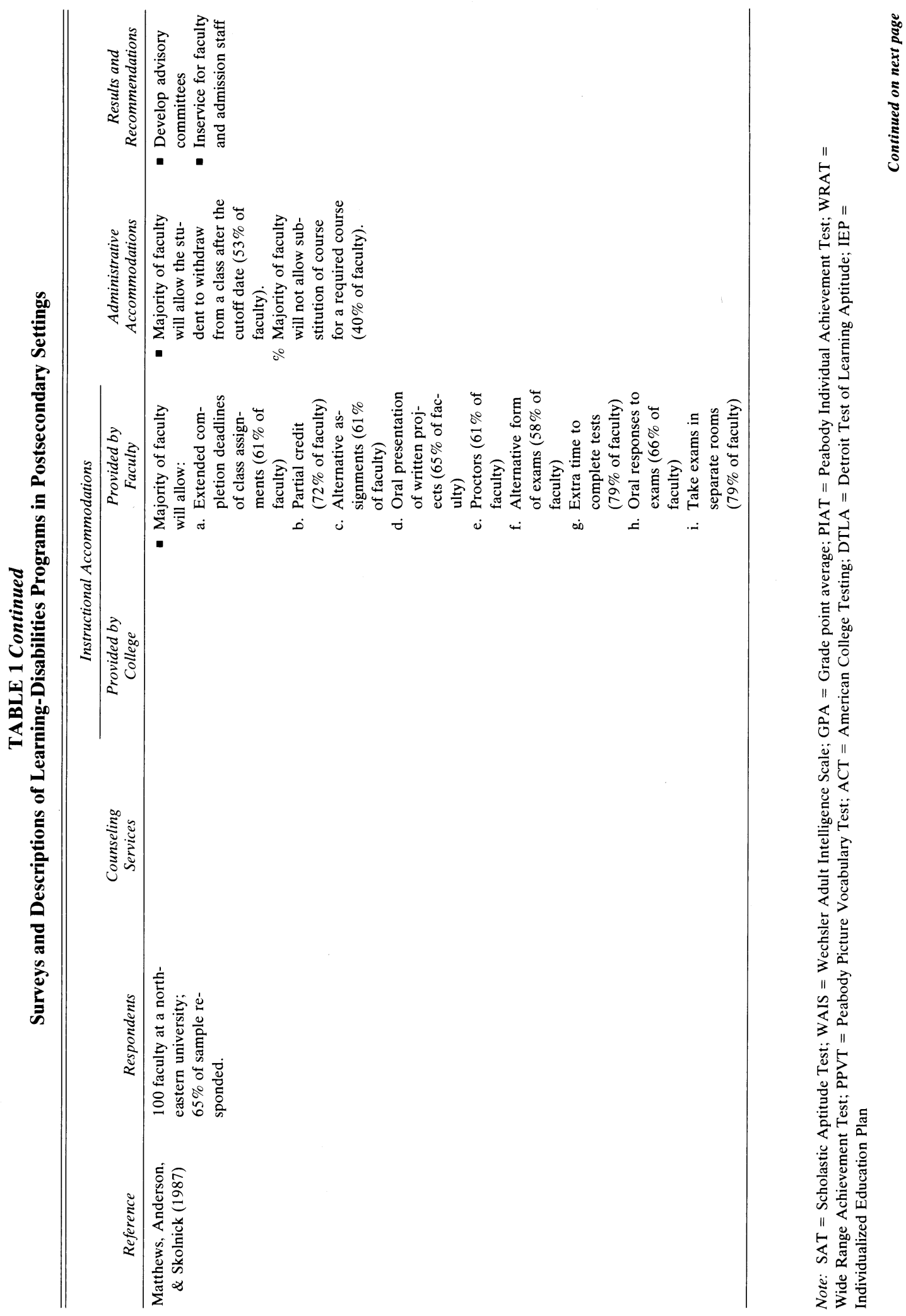


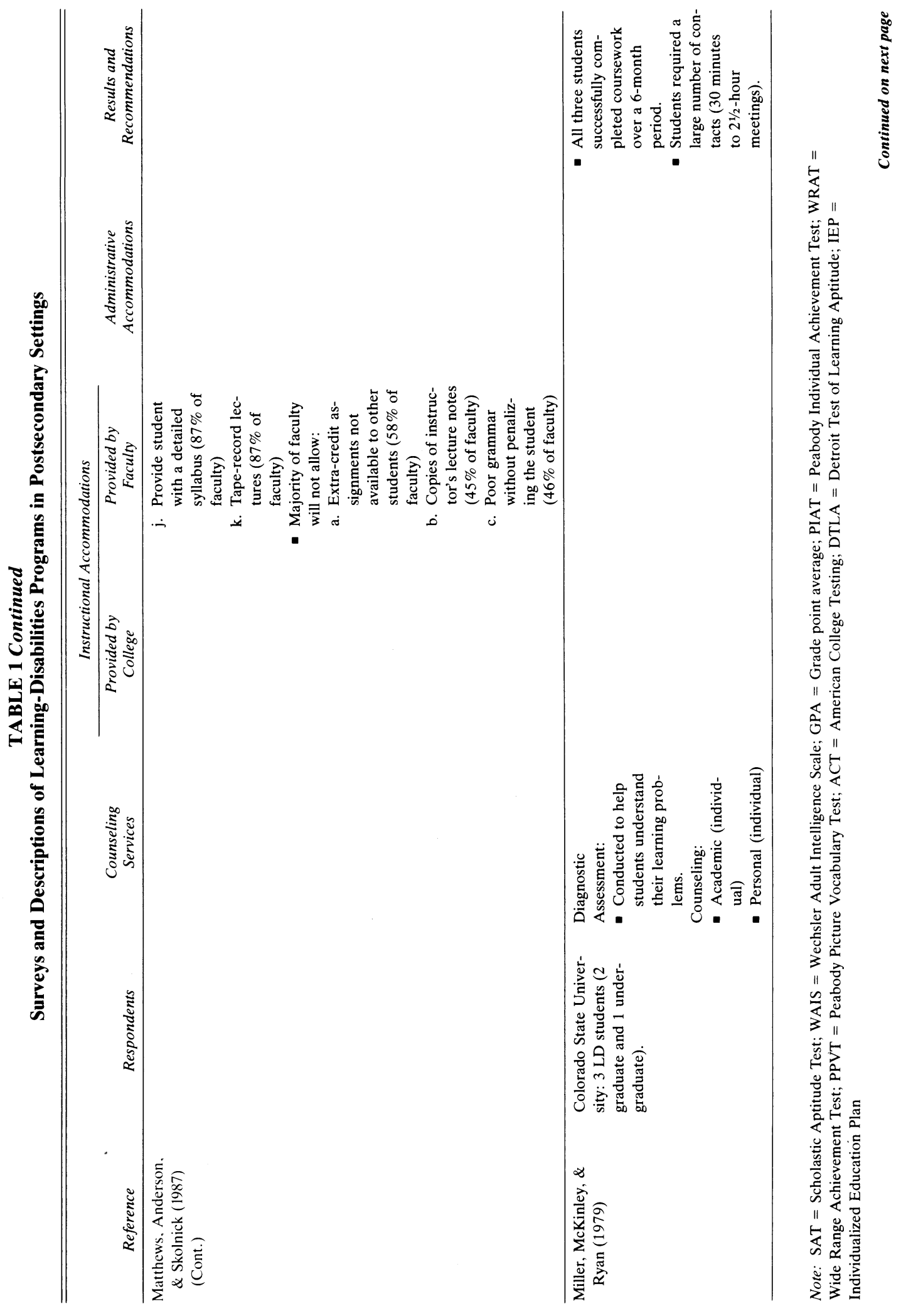



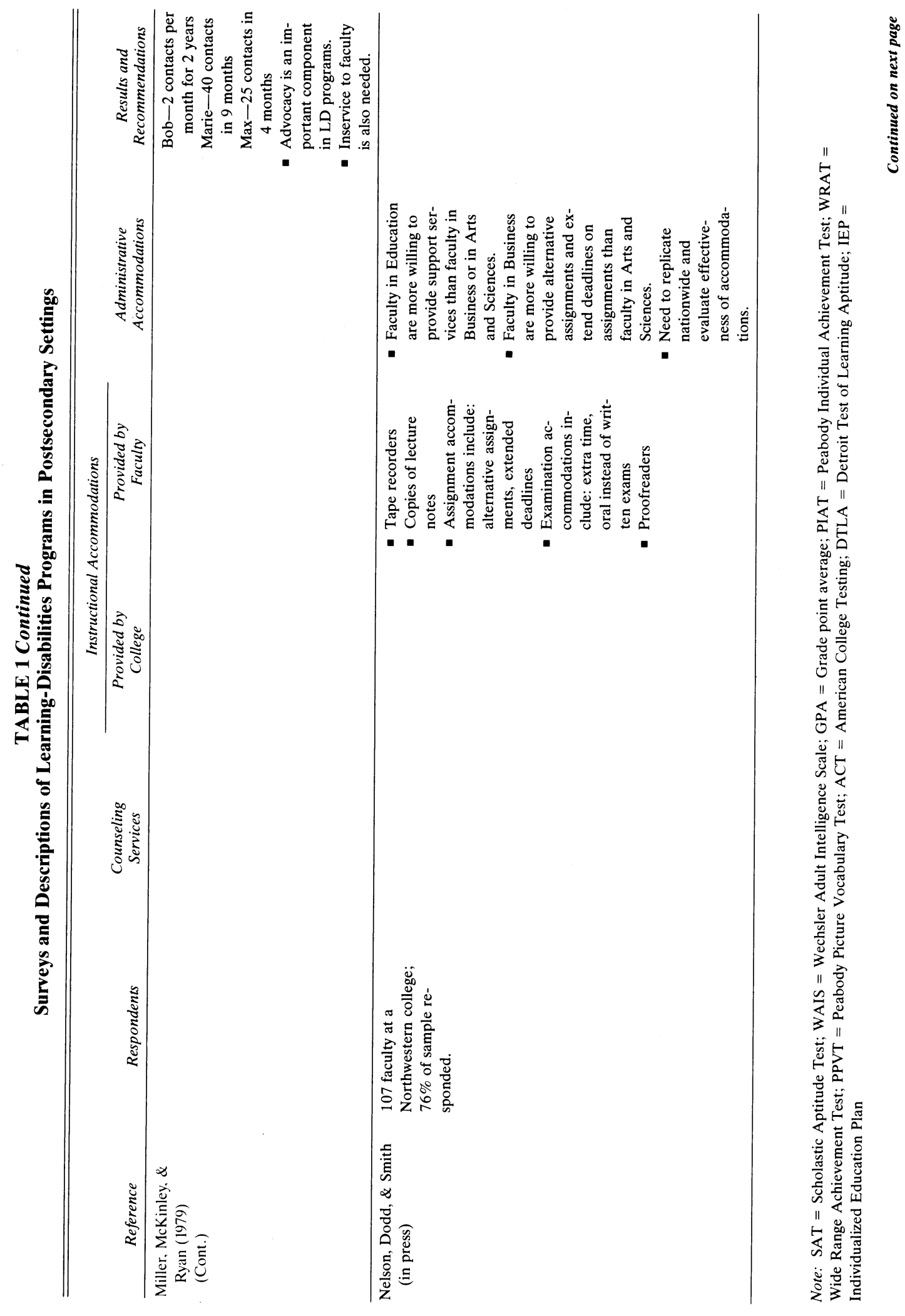


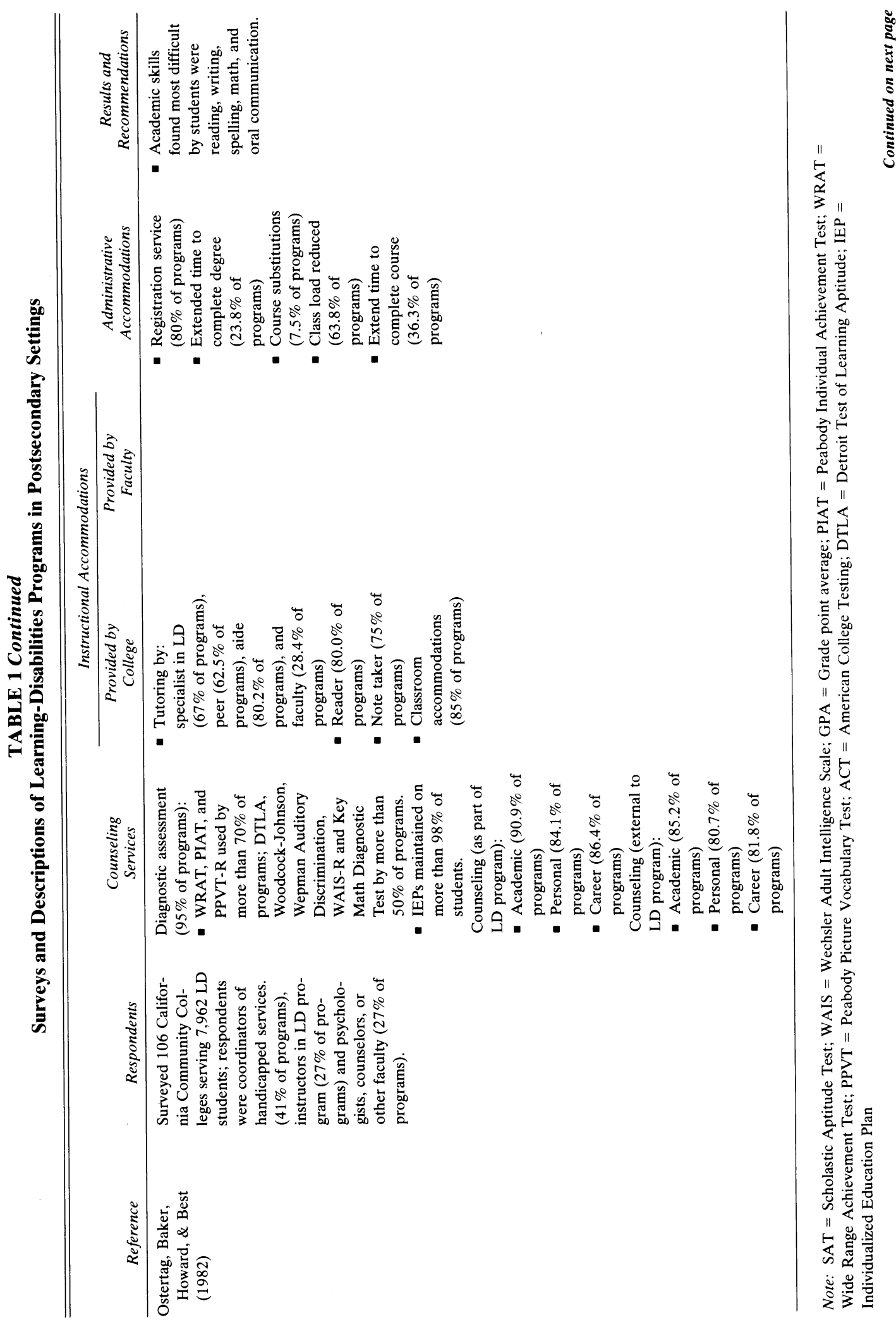




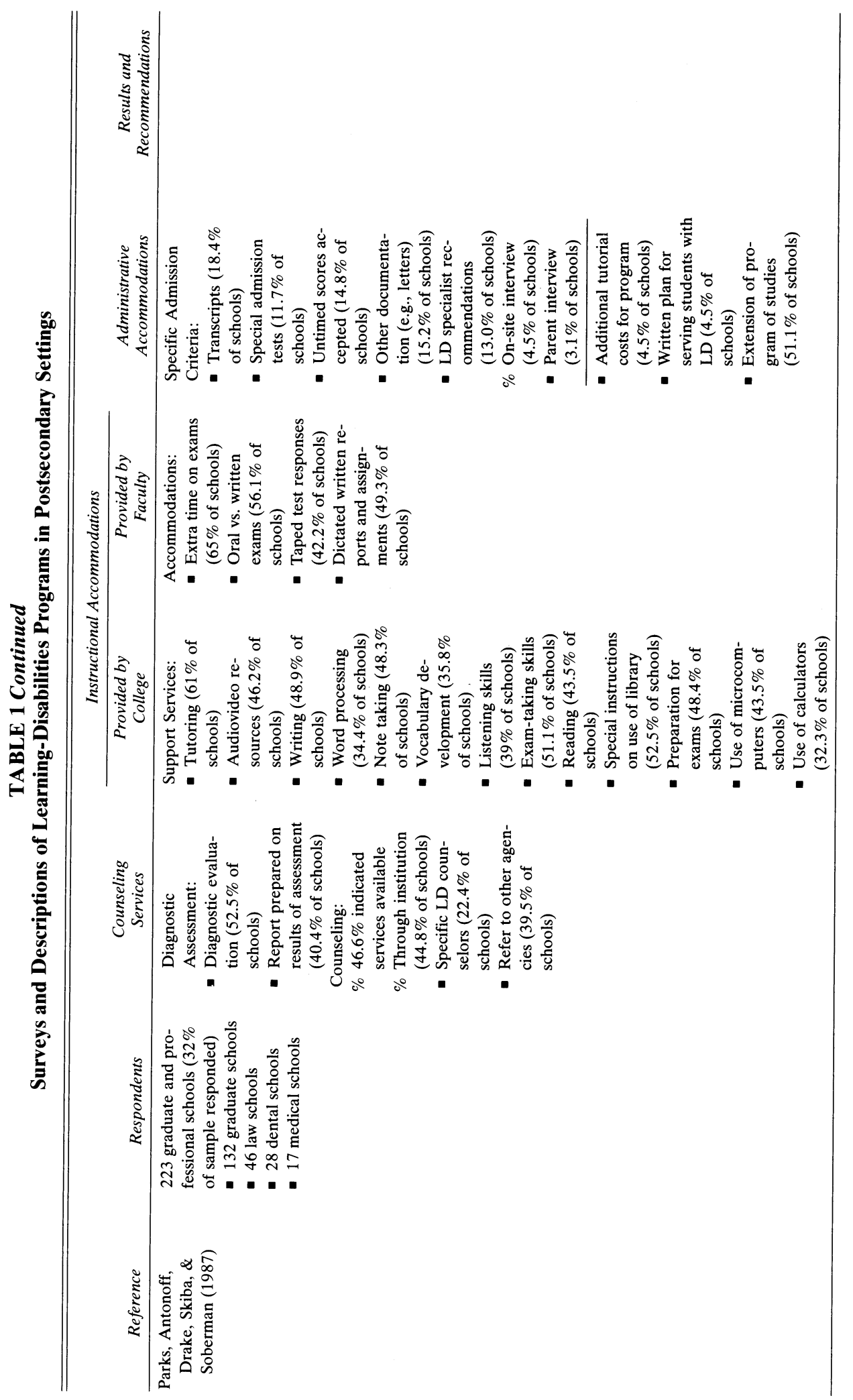

ㄴำ

3

苞画

节

总文

远.

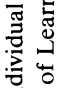

焉

年

흥

迎

范

बैं

造

龸

造吾

总

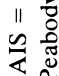

32

离

임

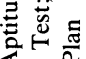

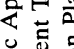

苋.

它胥

11

路

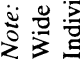




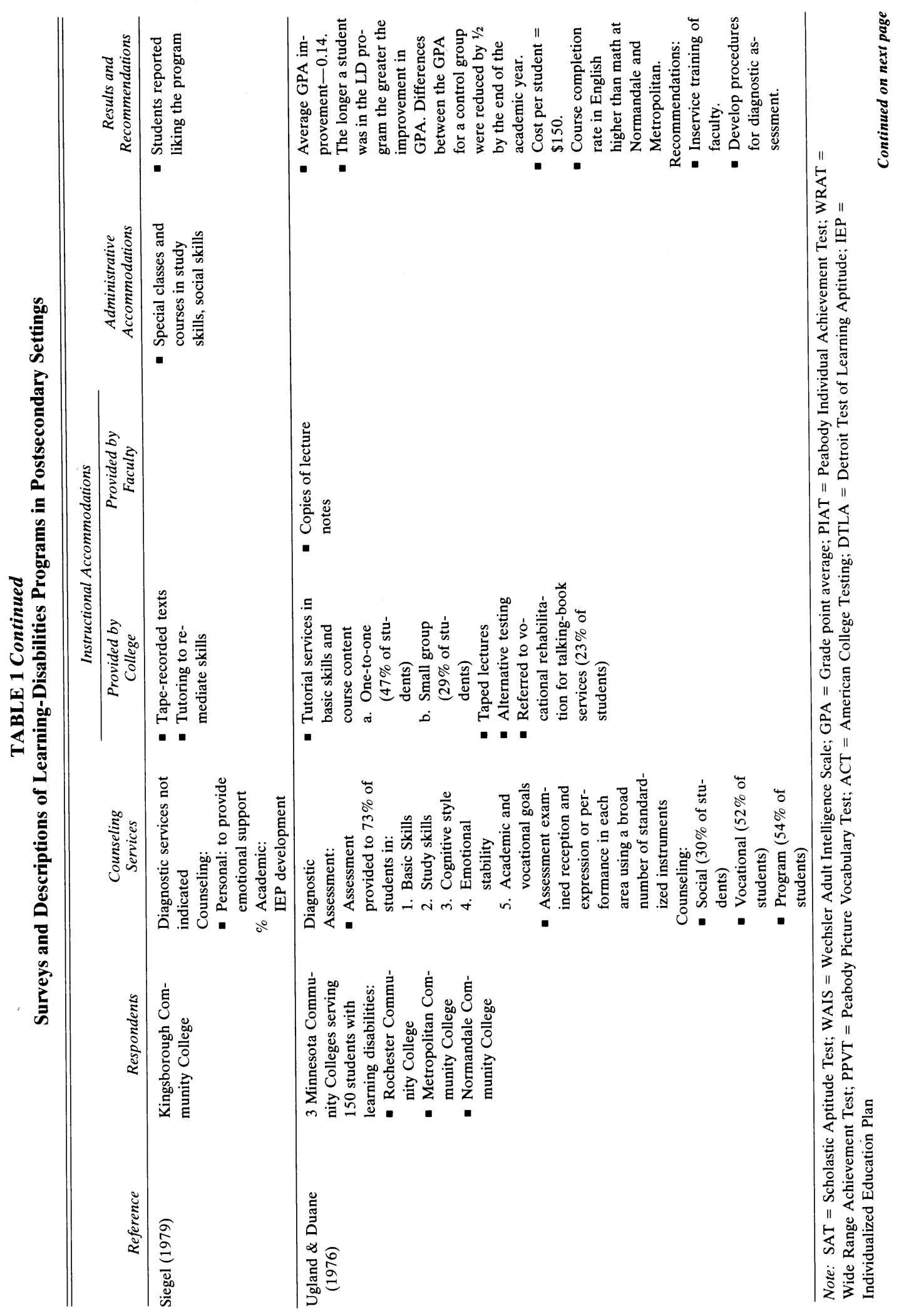



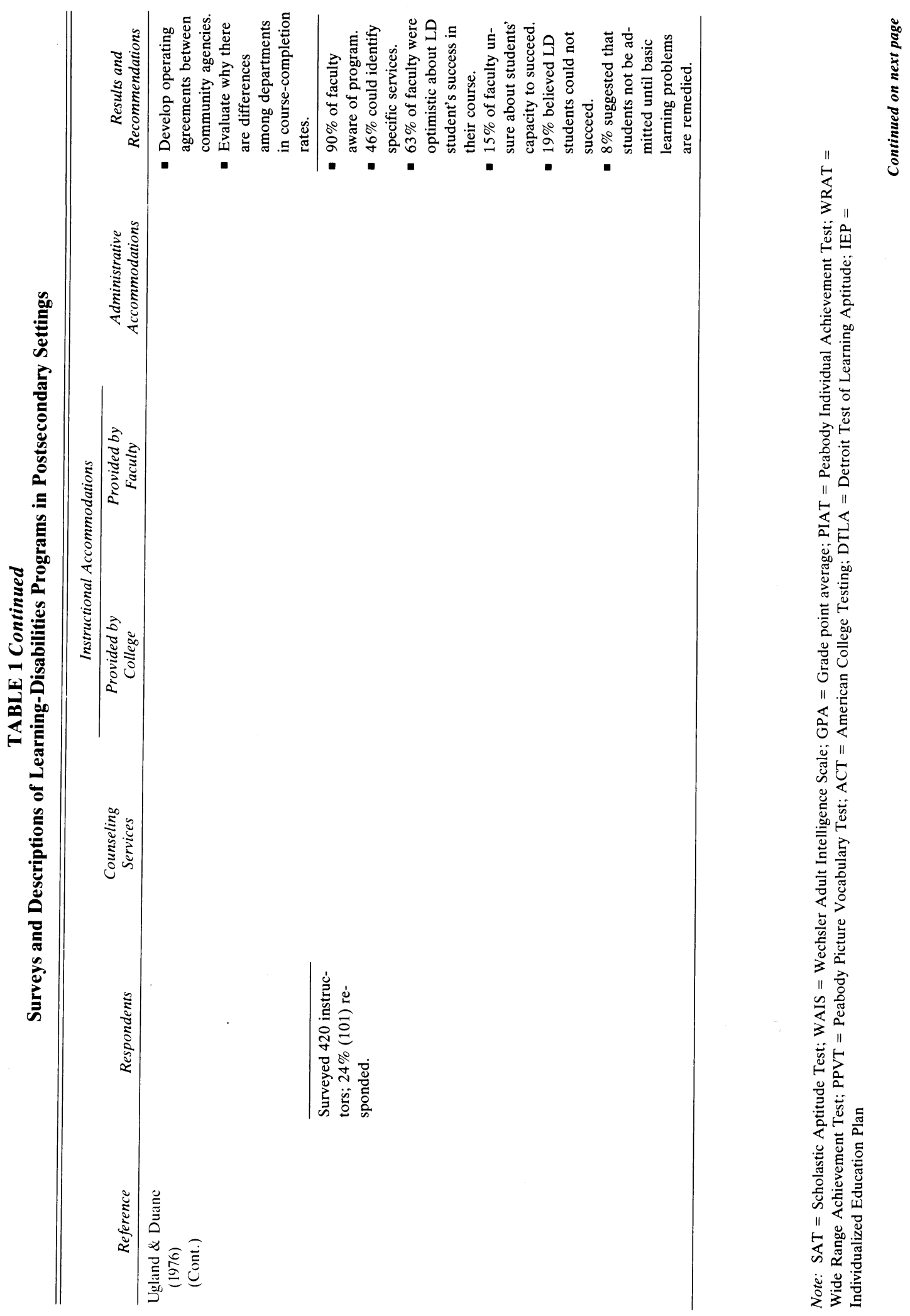


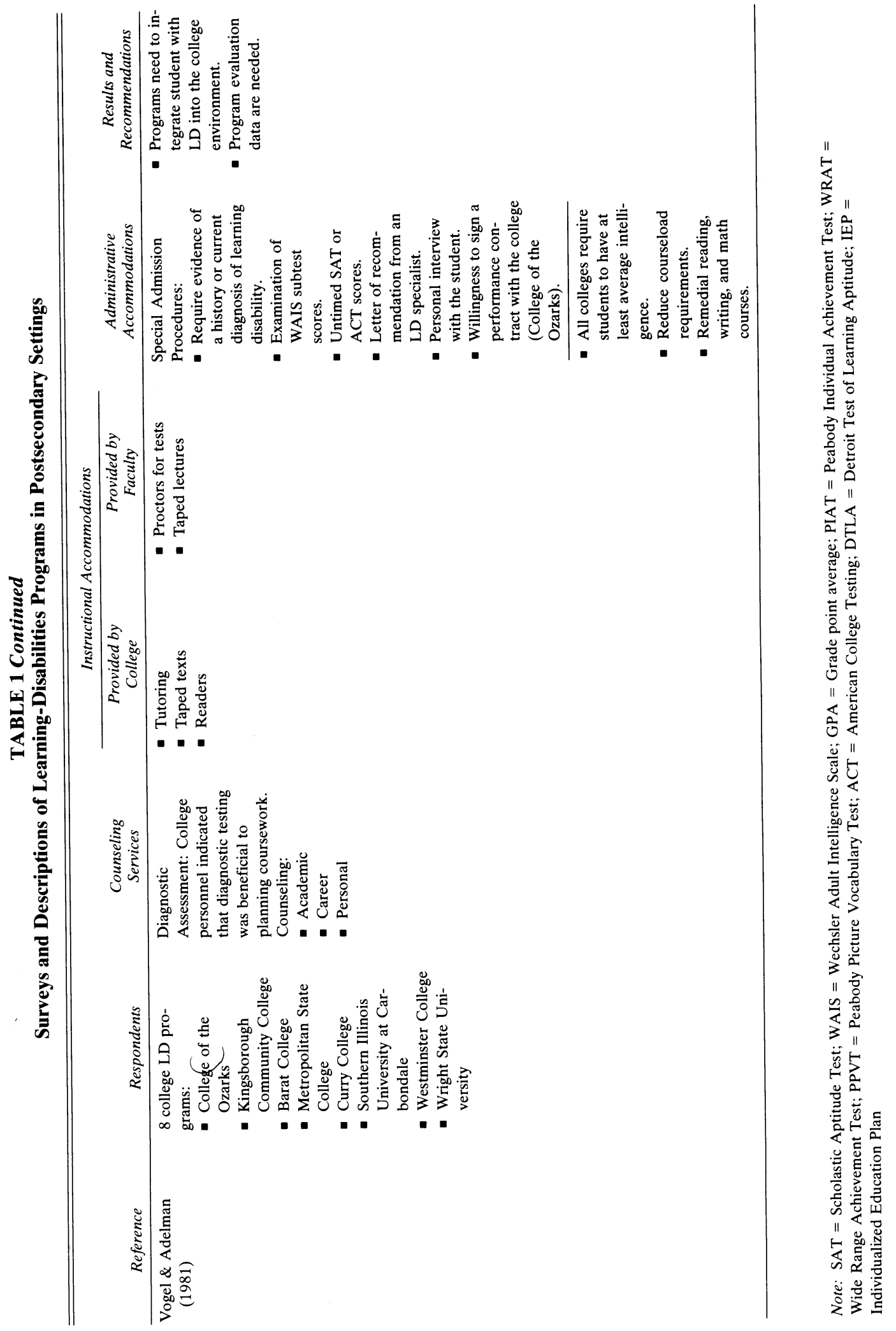


with learning disabilities (Blackburn \& Iovacchini, 1982; Decker et al., 1985; Stichart \& Mangrum, 1985; Vogel, 1982). In 12 of the 14 surveys or program descriptions, college officials reported that students were provided some type of counseling service.

Counseling services typically included (a) personal or social counseling, (b) academic or program counseling, and (c) career or vocational counseling. For instance, in three Minnesota Community College programs, 81 of 150 students $(54 \%)$ received social counseling, 45 of 150 students $(30 \%)$ received program counseling, and 78 of 150 students $(52 \%)$ received vocational counseling services (Ugland \& Duane, 1976). In another survey (Ostertag et al., 1982), college officials of 106 California community colleges reported that 96 of the community colleges $(91 \%)$ provided students academic counseling, 89 provided students personal counseling (84\%), and 91 provided students career counseling services $(86 \%)$.

Personal Counseling. Personal counseling was provided to help students with their social and interpersonal skills and to provide support in coping with the stresses of academia. Personal counseling services differed in how they were delivered (i.e., individual or group) and in who provided the counseling (i.e., specialist or peer). Strichart \& Mangrum (1985) suggested that specialists in learning disabilities should provide both individual and group counseling for academic stress. For example, at Kingsborough Community College, a specialist in learning disabilities conducted a social skills training program to teach students how to successfully interact with faculty and friends. In contrast, in the program at Adelphi University, social workers provided personal counseling individually and to groups of students (Barbaro, 1982). Initially a social worker interviewed each student and developed a psychosocial history. Based on the interview, each student received individual counseling. Group counseling sessions, conducted by the social worker, helped students manage their time and improve their communication skills with faculty and peers.

Academic Counseling. In 12 of the 14 surveys or program descriptions, college officials reported that students were provided academic counseling. In a majority of programs, aca- demic counseling involved a two-step process. First, diagnostic testing was conducted to determine program eligibility. Second, the test results were used to prescribe an individualized academic plan.

The quantity and quality of diagnostic workups varied widely among college programs. Most programs usually confined their assessment to basic IQ and achievement measures (Cordoni, 1982a; Ostertag et al., 1982). Diagnostic assessment was recommended in a number of academic areas, including receptive and expressive language, reading level, written language, and math reasoning and computation skills (Vogel, 1982). At three Minnesota community colleges, students were diagnostically tested in a number of areas, including oral and written language, academic skills, auditory and visual processes, study skills, and self-concept. Most colleges used standardized measures, such as the Wide Range Achievement Test, the Peabody Individual Achievement Test, the Detroit Test of Learning Aptitude, the Peabody Individual Achievement Test, the Detroit Test of Learning Aptitude, the Woodcock-Johnson Psychoeducational Test Battery, the Wepman Auditory Discrimination Test, the Wechsler Adult Intelligence ScaleRevised, and the Key Math Diagnostic Mathematics Test (Ugland \& Duane, 1976). Similarly, in Project Achieve at Southern Illinois University at Carbondale, students were assessed in academic areas, self-concept, and social skills (Cordoni, 1979).

Prescriptive planning, the second step in academic counseling, involved using the diagnostic assessment information to develop individualized education plans (IEPs) that specify long- and short-term objectives, learning strategies, and evaluation criteria. Ostertag et al. (1982) reported that IEPs were maintained for over $98 \%$ of the students in learning disabilities programs in California. The recommended components of an IEP at the college level varied across programs. In programs that emphasized support services, accommodations that directly assisted students in the college classroom were identified in the IEP. Typically, it was recommended that the IEP include compensatory strategies. At Southern Illinois University at Carbondale, students' IEPs included course content tutoring, talking books, use of tape recorders for lectures, computerized programs to cover course material, and alternative testing 
procedures (Cordoni, 1979). In programs that emphasized remedial services, it was recommended that IEP objectives address basic skill training as well as compensatory strategies.

Career Counseling. A variety of careercounseling services are recommended for learning disabled students (Hoy \& Gregg, 1986; Salend, Salend, \& Yanok, 1985; Siperstein, 1988; Strichart \& Mangrum, 1985). Siperstein (1988) suggested that students be provided career-awareness workshops (i.e., self-assessment, job exploration, and job assessment), job-search-strategy workshops (i.e., preparing a resume, writing cover letters, and interviewing techniques), and job-maintenance-skills workshops (i.e., goal setting, responding to employer feedback, interacting with fellow employees, and employee responsibilities). Career counseling, however, was identified as an important program component in only 3 of the 14 surveys or program descriptions (Ostertag et al., 1982; Ugland \& Duane, 1976; Vogel \& Adelman, 1981). For example, Ugland and Duane (1976) reported that of 150 students, 80 students received vocational counseling. The Kingsborough Community College program provided a comprehensive career or life planning course that included units in career awareness; job interviewing; resume writing; and evaluating one's own abilities, interests, and values (Vogel \& Adelman, 1981).

It is not clear, however, whether career counseling should be delivered in groups or individually, or whether the counseling should be provided by peers or by specialists.

\section{Instructional Accommodations}

Instructional accommodations include course modifications or support services to help students in college courses. Two types of instructional accommodations were identified. The first type of instructional accommodation is service provided by the college, such as notetakers, tutors, taped textbooks, interpreters and textbook readers, typists, and computers. The second type of accommodation is service provided by individual faculty, such as allowing students to tape-record lectures and providing alternative testing procedures, self-paced instructional modules, extended assignment deadlines, copies of lecture notes, and alternative assignments.
A majority of the college officials reported that learning disabled students were provided some instructional accommodation by the college. Specific instructional accommodations, however, varied across programs. For example, Ostertag et al. (1982) reported that students were provided tutorial support, textbook readers, and notetakers; whereas Ugland and Duane (1976) reported that students were provided only basic-skills and course-content tutoring. At Southern Illinois University at Carbondale, students received a broad array of services, including tutors, talking books, tape recorders, advocates, and computerized printouts that summarized course content (Cordoni, 1979).

Differences in tutoring services provided by colleges were consistent with their program objectives. College officials who advocated a remedial focus provided students basic-skills tutoring and course-content tutoring. In contrast, college officials who advocated a supportservice approach provided only course-content tutoring. Remedial services varied in how they were provided (i.e., individual tutoring, group tutoring, or special remediation courses) and in who provided the instruction (i.e., specialist, peer, or faculty). The College of the Ozarks and Barat College advocated intensive individual tutoring, but at Curry College, two or three students were tutored together (Vogel \& Adelman, 1981). Siperstein (1988) suggested that remedial services might be provided through a series of compensatory skill workshops, whereas students in California received tutoring for basic-skills deficits from a peer, from an aide, or from a faculty member (Ostertag et al., 1982). However, the basis for receiving tutoring from peers, aids, or faculty members was not identified.

Instructional accommodations provided by faculty included those classroom adaptations made at the discretion of individual faculty. These accommodations varied across programs. In a survey of directors of college programs, Mangrum \& Strichart (1983b) reported that instructional accommodations provided by faculty included additional time to complete coursework and alternative testing procedures. In contrast, Ugland and Duane (1976) reported that the instructional accommodations provided by faculty included allowing students to tape lectures, providing copies of lecture notes, and providing alternative test procedures. 
An important consideration was how willing faculty were to provide accommodations in their classes. In only three studies were faculty surveyed concerning their willingness to provide students different accommodations (Matthews, Anderson, \& Skolnick, 1987; Nelson, Dodd, \& Smith, in press; Ugland \& Duane, 1976). Matthews et al. surveyed all the faculty at a small northeastern public university. The majority of faculty were willing to provide daily class accommodations, such as tape recording lectures, and assignment and examination accommodations, such as alternative assignments and testing procedures. The majority of faculty were not willing to provide copies of the instructors' lecture notes, nor were they willing to provide disabled students with extra-credit assignments that were not available to other students. In another study, Nelson et al. surveyed all the faculty of a small northwestern university. Nelson et al. reported results similar to those reported by Matthews et al. In addition, Nelson et al. reported there were statistically significant differences among the College of Business, College of Arts and Sciences, and College of Education faculty in their willingness to provide students instructional accommodations. In general, College of Education faculty were more willing to provide course accommodations than were either Business or Arts and Sciences faculty. In addition, faculty in the College of Business were more willing to provide assignment and exam accommodations than were faculty in Arts and Sciences.

The results of these two studies suggest that faculty are willing to provide learning disabled students some accommodation in college classes. The type of assistance, however, is likely to vary based on the college. These conclusions should be viewed cautiously because the small samples in these studies may not be representative of college faculty in general.

\section{Administrative Accommodations}

Administrative accommodations include modifications in college admission policies and procedures and program funding mechanisms. Modifications in college admission policies that contribute to identifying students with learning disabilities are advantageous to both the student and the university. Early identification of students requiring services permits the integra- tion of services into a student's program during academic planning rather than in response to academic problems that develop later (Shaywitz \& Shaw, 1988). Strichart and Mangrum (1985) suggested that subtest scores on intelligence tests or on the Scholastic Aptitude Test (SAT) or American College Testing (ACT) college entrance exams should be used to determine college aptitude, and letters of recommendation from learning disabilities specialists should be considered in the admissions process. The admission modifications identified in the colleges reviewed include the acceptance of untimed entrance exams and weighted consideration of letters of recommendation from learning disabilities specialists, high school grades, and interviews with students. For example, Barbaro (1982) reported on 22 students who were admitted to Adelphi University based on untimed SAT scores, a review of a recent IEP, high school grades, and letters of recommendation from the learning disabilities specialist at the students' high schools.

A reduced courseload is also a recommended practice (Patton \& Polloway, 1987; Vogel, 1982). In three of the surveys, officials reported that students were allowed to take reduced courseloads and extend the length of their program of studies. In California, college officials reported that reduced courseloads were allowed in 67 of 106 community colleges $(63.8 \%)$ and extended programs of studies were permitted in 25 of the community colleges (23.8\%) (Ostertag et al., 1982). However, the length of time programs might be extended and how much courseloads might be reduced were not indicated.

One administrative function that has not been fully addressed is the funding mechanism for special programs or funding for students in special programs. Funding is an important consideration because the amount of money and the source of funds could influence the types of services included within the program. For instance, funding might affect whether a program provides individual counseling or group counseling; uses peer tutors or specialists; and provides remedial services as well as support services. Cordoni (1982b) reported that the cost of programs designed specifically for students with learning disabilities ranged from $\$ 3,000$ to $\$ 10,000$ per student per year. In contrast, Ugland and Duane (1976) suggested that a learning-disabilities program at the 
community college level might be built on existing services with little additional cost by using peer tutors and existing community resources. In some programs, these costs were met by the institution; in other programs, students were charged additional fees that ranged from $\$ 150$ to $\$ 2,000$ (Barbaro, 1982; Mangrum \& Strichart, 1983a, Ugland \& Duane, 1976). Parks, Antonoff, Drakes, Skiba, \& Soberman (1987) indicated that in $80 \%$ of the graduate and professional programs they surveyed, the costs of special services were met by the institution.

\section{CONCLUSION AND FUTURE RESEARCH NEEDS}

It is evident that many learning disabled students attend community colleges and traditional 4-year institutions (ACLD, 1982; Decker et al., 1985; Ostertag et al., 1982; Ugland \& Duane, 1976; White et al., 1982). Three factors are associated with how services are provided to these students. First, differences in program emphasis and service delivery reflect differences in program objectives. Some college officials reported that the principle objective of their program was to provide students basic-skills remediation. For example, at Kingsborough Community College, a central program component was remediation of basic skills through peer tutoring and Audio Tutorial Lab (Siegel, 1979). In contrast, some college officials indicated that the objective of their program was to support students in classes rather than remediate their basic-skills deficits. For example, at Wright State University, students were provided course-content tutoring, exam proctors and readers, access to taperecorded textbooks, and assistance from Vocational Rehabilitation (Bireley \& Manley, 1980; Vogel \& Adelman, 1981). Still other programs emphasized remediation of skill deficits and support services. For instance, at three Minnesota community colleges, students were provided basic-skills tutoring and remedial courses, as well as course-content tutoring, taped lectures, and alternative testing procedures (Ugland \& Duane, 1976).

Provision of remedial services or support services often reflects differences in the expected entry-level skills of students with learning disabilities and differences in how program administrators view the educational role of postsecondary institutions (Vogel \& Adelman, 1981). Kahn (1980) indicated that the teacher's responsibility at the secondary and junior college level is to teach content and not remediate learning problems. Proponents of support services also have argued that most often a university student does not have the time or energy to complete a remedial program in addition to regular coursework (Ingram \& Dettenmaier, 1987). In contrast, basic-skills remediation has been viewed as a necessary ingredient for success in college-level coursework (Sedita, 1980).

Second, the mission of the college appears to influence the types of services provided students. Community colleges have provided opportunities ranging from preparation for the general equivalency diploma (GED) to noncredit special interest courses and vocational training courses, whereas traditional 4-year institutions offer students academic training in a range of specific fields. Typically, 4-year institutions have emphasized remedial training less than have community colleges.

Third, the amount of funding allocated to the program may be associated with how services are delivered to students. For example, the funds available to a program might determine whether the tutors are specialists in the field of learning disabilities or peer tutors, and whether a program provides individual or group counseling.

There is little research available that college administrators might use to design a service program for students with learning disabilities (Cordoni, 1979, 1982b; Gajar et al., 1982, Putnam, 1984; Sedita, 1980). First, research is needed on measures to identify adults with learning disabilities. This research should lead to establishing guidelines for determining program eligibility (Decker et al., 1985; Gray, 1981b; Hoy \& Gregg, 1986).

Second, descriptive research is needed to identify services provided learning disabled students. In particular, a national survey that addresses the course accommodations that faculty in community colleges and universities are willing to provide students would be useful information for career counselors in secondary schools and academic advisors in universities. In addition, research that describes the setting demands of postsecondary educational environments would be useful in designing learning plans for learning disabled students. Research 
in setting demands has provided a foundation for developing a number of intervention strategies for high school learning disabled students (Anderson-Inman, Walker, \& Purcell, 1984; Schumaker \& Deshler, 1984). Similar analyses of setting demand variables in postsecondary settings would provide a foundation for developing an effective and comprehensive service system in postsecondary education.

Third, little research examines the effect of individual program components on student achievement or the most effective and efficient way to structure program components. For example, Deshler and Graham (1980) suggested that material may be taped verbatim or text may be paraphrased and summarized. It is not clear how these approaches affect students' class performance or if a particular structure of taped material might influence the development of study skills.

Finally, there is a need for longitudinal studies that examine what students do after graduation and that identify the services that students found most useful. This kind of information will provide program administrators with quantitative as well as qualitative data with which to evaluate their learning disabled programs.

Postsecondary careers are composed of transitions that include entering college, adapting to academic and social changes, and exiting college (Siperstein, 1988). It is clear that many postsecondary institutions recognize both the need and the responsibility to provide services that will assist individuals with disabilities to succeed in each transition. It is also clear, however, that we must devote more research resources and expend greater effort in developing programs that are both effective and cost efficient.

\section{REFERENCES}

Adult Committee of the Association of Children with Learning Disabilities (ACLD) Vocational Committee. (1982). Preliminary report of the ACLD Vocational Committee survey of LD adults. ACLD Newsbriefs \# 145, 20-23.

Anderson-Inman, L., Walker, H. M., \& Purcell, J. (1984). Promoting the transfer of skills across settings: Transenvironmental programming for handicapped students in the mainstream. In W. L. Heward, T. E. Heron, D. S. Hill, \& J. Trap-Porter (Eds.), Focus on behavior analysis in education (pp. 18-37). Columbus, OH: Charles E. Merrill.
Barbaro, F. (1982). The learning disabled college student: Some considerations in setting objectives. Journal of Learning Disabilities, 15, 599-603.

Bireley, M., \& Manley, E. (1980). The learning disabled student in a college environment: A report of Wright State University's program. Journal of Learning Disabilities, 13, 12-15.

Blackburn, J. C., \& Iovacchini, E. V. (1982). Student service responsibilities of institutions to learning disabled students. College and University, 52, 208-217.

Blalock, G., \& Dixon, D. (1982). Improving prospects for the learning disabled. Topics in Learning and Learning Disabilities, 2, 69-78.

Cordoni, B. (1979). Assisting dyslexic college students: An experimental program design at the university. Bulletin of the Orton Society, 29, 263-268.

Cordoni, B. K. (1982a). Secondary education: Where do we go from here? Journal of Learning Disabilities, 15, 265-266.

Cordoni, B. K. (1982b). Services for college dyslexics. In R. N. Malatesha \& P. G. Aaron (Eds.), Reading disorders: Varieties and treatments (pp. 435-448). New York: Academic Press.

Decker, T., Polloway, E., \& Decker, B. (1985). Help for the LD college student. Academic Therapy, 20, 339-345.

Deshler, D. D., \& Graham, S. (1980). Tape recording educational materials for secondary students. Teaching Exceptional Children, 12, 5254.

Gajar, A. H., Murphy, J. P., \& Hunt, F. M. (1982). A university program for learning disabled students. Reading Improvement, 19, 282-288.

Gray, R. (1981a). Serving adults with presumed learning disabilities. Journal of Developmental and Remedial Education, 4(2), 3-5, 33.

Gray, R. A. (1981b). Services for the LD Adult. A working paper. Learning Disability Quarterly, 4, 426-434.

Hoy, C., \& Gregg, N. (1986, Summer). Learning disabled students: An emerging population on college campuses. The Journal of College Admissions, 112, 10-14.

Ingram, G. F., \& Dettenmaier, L. (1987). Learning disabled college students and reading problems. Academic Therapy, 22, 513-519.

Kahn, M. S. (1980). Learning problems of the secondary and junior college learning disabled student: Suggested remedies. Journal of Learning Disabilities, 13, 445-449.

Mangrum, C. T., \& Strichart, S. S. (1983a). College possibilities for the learning disabled: Part One. Learning Disabilities, 2(5), 57-68.

Mangrum, C. T., \& Strichart, S. S. (1983b). College possibilities for the learning disabled: Part Two. Learning Disabilities, 2(6), 69-81. 
Matthews, P., Anderson, D., \& Skolnick, B. (1987). Faculty attitude toward accommodations for college students with learning disabilities. Learning Disabilities Focus, 3, 46-52.

Miller, C. D., McKinley D. L., \& Ryan, M. (1979). College students: Learning disabilities and services. The Personnel and Guidance Journal, 58(3), 154-158.

Nelson, J. R., Dodd, J. M., \& Smith, D. (in press). An analysis of accommodations faculty are willing to make for learning disabled students in higher education. Journal of Learning Disabilities.

Ostertag, B. A., Baker, R. E., Howard, R. F., \& Best, L. (1982). Learning disabled programs in California community colleges. Journal of Learning Disabilities, 15, 535-538.

Parks, A. W., Antonoff, S., Drake, C., Skiba, W. F., \& Soberman, J. (1987). A survey of programs and services for students with learning disabilities in graduate and professional schools. Journal of Learning Disabilities, 20, 181-189.

Patton, J. R., \& Polloway, E. A. (1987). Analyzing college courses. Academic Therapy, 22, 273-280.

Putnam, M. L. (1984). Postsecondary education for learning-disabled students: A review of the literature. Journal of College Student Personnel, 25, 68-75.

Salend, S. J., Salend, S. M., \& Yanok, J. (1985). Learning disabled students in higher education. Teacher Education and Special Education, 8, 49-54.

Schumaker, J. B., \& Deshler, D. D. (1984). Setting demand variables: A major factor in program planning for the LD adolescent. Topics in Language Disorders, 4(2), 22-40.

Sedita, J. (1980). Help for the learning disabled college students. Prides Crossing, MA: Landmark School.

Shaywitz, S. E., \& Shaw, R. (1988). The admissions process: An approach to selecting learning disabled students at the most selective colleges. Learning Disabilities Focus, 3(2), 81-86.

Siegel, D. (1979). Help for learning disabled college students. American Education, 15, 17-21.

Siperstein, G. N. (1988). Students with learning disabilities in college: The need for a programmatic approach to critical transitions. Journal of Learning Disabilities, 21, 431-436.

Strichart, S. S., \& Mangrum, C. T. (1985). Selecting a college for the LD student. Academic Therapy, $20,475-479$.

Ugland, R., \& Duane, G. (1976). Serving students with specific learning disabilities in higher education. A demonstration project at three Minnesota community colleges (ED. 135434). Washington DC: Office of Education.

\section{TITLES FOR TEACHERS}

Accelerated Human Development 1405 Miramar St.

Valdosta, GA 31601

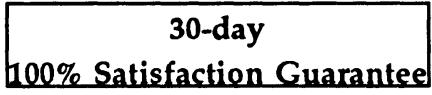

Workshop Manuals \& Handouts

$$
\text { Topics }
$$

- Proactive Programming - Managing Aggression

- Legal Self-Defense - Best Training Practices

- Individualized Planning - Coaching Cooking Skill - Strategy \& Self-Instruction

- Environmental Accommodation

- Birth to Five Transition - Counseling

- Increased Achievement Motive - Technological Aids

- On Task Behavior - Quick Learning Guide

Send for catalog and receive a $20 \%$ discount woucher.

Hurry! Vouchers are limited to 300

(c) 1989 ACCELERATED HUMAN DEVELOPMENT $20 \%$ OFF

Vogel, S. A. (1982). On developing LD college programs. Journal of Learning Disabilities, 15, 518-528.

Vogel, S. A., \& Adelman, P. (1981). College and university programs designed for learning disabled adults. Illinois Council for Exceptional Children Quarterly, 1, 12-18.

White, W. J., Alley, G. R., Deshler, D. D., Schumaker, J. B., Warner, M. M., \& Clark, F. L. (1982). Are there learning disabilities after high school? Exceptional Children, 49, 273-274.

The development of this article was partially supported by Grant \#G008780011 from the Office of Special Education Programs, U.S. Department of Education. The authors acknowledge Pamela Hudson and Deborah Smith for their helpful suggestions on an earlier draft of this mansucript. Requests for reprints should be sent to Benjamin Lignugaris/Kraft, Department of Special Education, Utah State University, Logan, UT 84322-6500.

Manuscript received October 1988; revision accepted March, 1989. 